\title{
P275: Prevention of healthcare-associated infections associated with care: results of the neonatal service audit in Beni-Messous university hospital Algiers in 2012
}

\author{
G Brahimi*, S Mounes, R Belkaid, A Soukehal
}

From 2nd International Conference on Prevention and Infection Control (ICPIC 2013)

Geneva, Switzerland. 25-28 June 2013

\section{Introduction}

The prevention of the risk of contamination of the newborn environment requires strict organization of care.

\section{Objectives}

Evaluate adherence and compliance to maintenance of incubators and adherence to hand hygiene $(\mathrm{HH})$ and good practices related to the installation of peripheral venous catheters (PVCs).

\section{Methods}

The audit took place from 1 to 31 March 2012 in the neonatology unit by questioning and observing the paramedical personnel.

\section{Results}

The unit has 35 beds (20 incubators and 15 bassinets), the 20 caregivers were audited, $70 \%$ nursery and $20 \%$ of graduated nurses.

Daily cleaning of the inside of the incubator was made in $80 \%$ of cases, the disinfectant spray was used in $25 \%$. Cleaning the outside of the incubator was performed with water in $81.6 \%$. Of 105 treatments performed, the $\mathrm{HH}$ compliance rate before and after the procedure is $62.8 \%$. Adequacy in both opportunity and type of $\mathrm{HH}$ was found in $54.3 \%$. When installing a PVC, the cleaning phase was observed in $15 \%$ of cases, with no rinsing or drying. No healthcare worker respected the time need for antiseptic drying. Sterile gauzes are used in

Department of Epidemiology and Preventive Medicine, CHU Béni-Messous, Algiers, Algeria

\section{Algiers, Algeria}

$55 \%$ of cases. Gloves were used for the placement of a PVC in $20 \%$.

\section{Conclusion}

The risk of infection related to the maintenance procedures of incubators and gestures of care for the newborn is identified; it could be avoided by the application of appropriate and validated procedures.

\section{Competing interests \\ None declared.}

Published: 20 June 2013

doi:10.1186/2047-2994-2-S1-P275

Cite this article as: Brahimi et al:: P275: Prevention of healthcareassociated infections associated with care: results of the neonatal service audit in Beni-Messous university hospital Algiers in 2012 Antimicrobial Resistance and Infection Control 2013 2(Suppl 1):P275.

\section{Submit your next manuscript to BioMed Central} and take full advantage of:

- Convenient online submission

- Thorough peer review

- No space constraints or color figure charges

- Immediate publication on acceptance

- Inclusion in PubMed, CAS, Scopus and Google Scholar

- Research which is freely available for redistribution 